九州大学学術情報リポジトリ

Kyushu University Institutional Repository

\title{
Acreage Response of Pulses to Prices Under Agricultural Market Reform in Myanmar
}

Moe, Aung Kyaw

Graduate School of Bioresource and Bioenvironmental Sciences, Kyushu University

Yutaka, Tomoyuki

Faculty of Agriculture, Kyushu University

Fukuda, Susumu

Faculty of Agriculture, Kyushu University

Kai, Satoshi

Faculty of Agriculture, Kyushu University

https://doi.org/10.5109/9339

出版情報: 九州大学大学院農学研究院紀要. 52 (2)，pp.481-488，2007-10-29. Faculty of Agriculture, Kyushu University

バージョン：

権利関係 : 


\title{
Acreage Response of Pulses to Prices Under Agricultural Market Reform in Myanmar
}

\author{
Aung Kyaw MOE ${ }^{1}$, Tomoyuki YUTAKA, Susumu FUKUDA \\ and Satoshi KAI* \\ Laboratory of Food Marketing, Division of Industrial Organization of Agribusiness, \\ Department of Agricultural and Resource Economics, Faculty of Agriculture, \\ Kyushu University, Fukuoka 812-8581, Japan \\ (Received June 30, 2007 and accepted July 17, 2007)
}

\begin{abstract}
Estimation of agricultural supply response is essential to investigate the impact of changes of agricultural marketing and pricing policies. Before market reform in Myanmar, domestic and export markets were monopolized by government and farmers had to sell quota of their marketable surplus at fixed prices. After market reform, compulsory delivery system of agriculture produce was discontinued and private marketing was well-developed in domestic markets as well as in export of crops such as pulses. This article assesses the impact of market reform by examining acreage response to price with Nerlove partial-adjustment model covering yearly data from 1988-2004. Acreage response to liberalization of prices and marketing was statistically significant in export crops, Black gram, Green gram, Pigeon pea and Chickpea except Soybean with lack of export demand. Although the short-run elasticity of acreage was less than unity, the long-run elasticity was quite greater than unity. Agricultural market reform, with price incentive to farmers, can induce the motivation of production. However, complementary interventions for the improvement of infrastructure, marketing, access to inputs and credits, production technology etc are still prerequisite.
\end{abstract}

\section{INTRODUCTION}

Agricultural prices determine agricultural output or supply in the forms of yield or acreage or production. The issue of agricultural supply response is a very important one as it has an impact on growth, poverty and development. Not surprisingly, this issue is central in many structural adjustment programs in less developed countries. Indeed, the size of agricultural supply response is informative about whether "a policy of fixing agriculture through lower farm prices or through overvalued exchange rates and industrial policies will generate resources for investment in other sectors of the economy or whether such policies will retard agricultural growth and create food and input bottlenecks which eventually bring down the rate of growth of the economy as the whole" (Chhibber, 1989).

Many studies, most famously Krueger et al. (1991) have documented the implicit and explicit taxation of the agriculture sector. For example, export crop marketing like rice, pulses, etc., has proved an especially mean to tax agriculture by simply setting producer prices below world prices. Since 1970s and 1980s, evidence has mounted that many interventions put in place to facilitate growth have instead become an impediment to growth (World Bank, 1983). Many governments have assigned monopoly and monopsony power by restricting or even prohibiting private trade, and using parastatal agencies or heavy-handed market-

\footnotetext{
1 Laboratory of Food Marketing, Division of Industrial Organization of Agribusiness, Department of Agricultural and Resource Economics, Graduate School of Bioresource and Bioenvironmental Sciences, Kyushu University

* Corresponding author (E-mail: satokai@agr.kyushu-u.ac.jp)
}

ing boards to assemble, transport, and market commodities. Many marketing boards were similarly inefficient, irrational, wasteful, and fiscally unsustainable, drawing enormous resources that might have been better employed elsewhere.

On the other hand, government influence prices indirectly by providing subsidies on commodities to consumers or on inputs to producers. Many governments taxed producers directly and indirectly to keep food prices low and favor urban interests (Krueger et al., 1991 and Mundlak et al., 1989). Government intervention such as lowering producer's prices adversely affected on production, undermined the programs, and led government official prices in domestic to become pan seasonal, pan territorial and detached from international prices. Consequently, illegal or parallel markets emerged, and official monopolies could not be maintained.

It is therefore essential to assess the 'price impact' and to understand to what extent the policies adopted affect the production of agricultural commodities, in what direction the distortions take effect, and what possible adjustments can be made to improve policy. Moreover, reliable supply response estimates are particularly important when predicting the impact of changes of agricultural marketing and pricing policies. These reasons underlie the importance of farmer response to economic incentives for the policy-maker. Therefore, this paper attempts to comprehend which crops are responsive to price under agricultural market reform and to measure this responsiveness in order to assess whether reformation of agricultural markets, where it increases the effective prices paid to farmers, can be effective in stimulating production, especially in acreage response. 


\section{GENERAL DISCRIPTION OF BACKGROUND SITUATION}

\section{Role of agriculture and pulses' sector}

The economy of Myanmar is agrarian in nature with production, consumption and export activities domi-

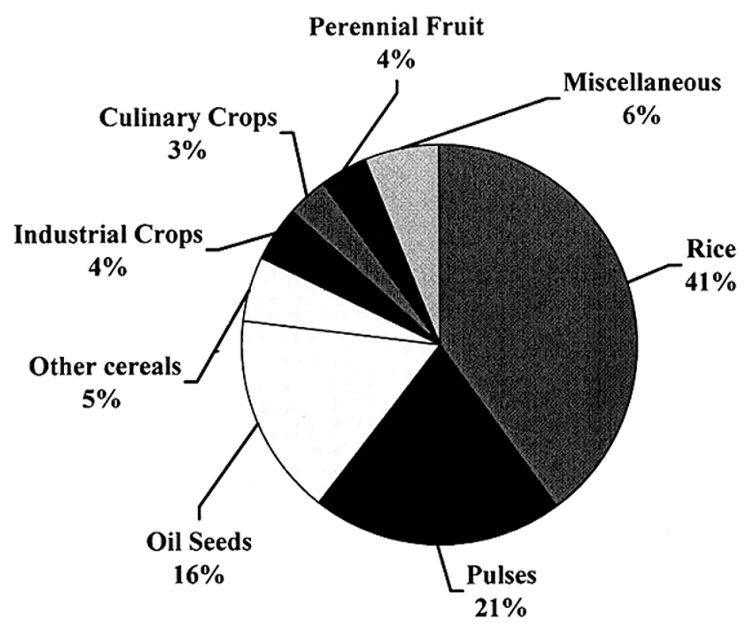

Fig. 1. Sown Area Percentage of Various Crops in Myanmar. nated by basic foods. Economic development of the county depend mainly on the agricultural sector, since about $75 \%$ of the population who lives in rural areas, engages in agricultural, livestock and fisheries sector for their livelihoods, about $63 \%$ of the total labor force joins in agricultural production, and about $43 \%$ of the gross domestic product (GDP) shares in agriculture (Table 1).

The sown acreage of pulses is 3.19 millions hectares, being the second largest sown area after rice with $21 \%$ of the total sown areas (Fig. 1).

Pulses have also become the major foreign earner among agricultural commodities, sharing in $62.7 \%$ at 2003/04 (Table 2).

\section{Marketing policies before agricultural market reforms}

In Myanmar, after independence the government made attempts at the state monopolization of trade in farm products as well as at price controls chiefly with an eye to (1) eliminate the domination of trade in farm products by Indian and Chinese merchants, and (2) make the export earnings on farm products as an important source of state income. With the aim the government set up the state agricultural products board

Table 1. Sector Contribution to Gross Domestic Product (At Constant Producers' Prices)

(Value In Kyats Million)

\begin{tabular}{|c|c|c|c|c|c|c|c|}
\hline & \multirow[b]{2}{*}{ Goods } & \multicolumn{3}{|c|}{ Goods } & \multirow[b]{2}{*}{ Services } & \multirow[b]{2}{*}{ Trade Value } & \multirow[b]{2}{*}{$\begin{array}{c}\text { GDP Value } \\
(1+2+3)\end{array}$} \\
\hline & & Agriculture & $\begin{array}{l}\text { Livestock } \\
\text { \& Fishery }\end{array}$ & Forestry & & & \\
\hline & (1) & & & & (2) & (3) & \\
\hline 1988/89 Value & $28,004.2$ & $18,137.6$ & $3,780.2$ & 677.4 & $8,578.7$ & $10,558.2$ & $47,141.1$ \\
\hline$\%$ & 59.4 & 38.5 & 8.0 & 1.4 & 18.2 & 22.4 & 100.0 \\
\hline 1998/99 Value & $47,489.1$ & $27,417.3$ & $5,883.3$ & 802.2 & $15,224.4$ & 16.755 .2 & $79,460.2$ \\
\hline$\%$ & 59.8 & 34.5 & 7.5 & 1.0 & 19.2 & 19.2 & 100.0 \\
\hline 1999/00 Value & $47,480.6$ & $30,297.3$ & $6,988.0$ & 839.0 & $16,567.3$ & $18,354.3$ & $88,157.0$ \\
\hline$\%$ & 59.8 & 34.4 & 7.9 & 1.0 & 18.8 & 20.8 & 100.0 \\
\hline 2000/01 Value & $60,669.9$ & $33,658.9$ & $8,310.3$ & 866.5 & $18,659.8$ & $20,945.1$ & $100,274.8$ \\
\hline$\%$ & 60.5 & 33.6 & 8.3 & 0.9 & 18.6 & 20.9 & 100.0 \\
\hline 2001/02 Value & $680,456.8$ & $476,825.9$ & $78,1218.9$ & $6,062.1$ & $76,981.1$ & $234,961.7$ & $992,339.6$ \\
\hline$\%$ & 68.6 & 48.0 & 7.9 & 0.6 & 7.8 & 23.7 & 100.0 \\
\hline 2002/03 Value & $2,091,800.0$ & $1,409,400.0$ & $258,600.0$ & $16,400.0$ & $34,260.0$ & $750,300.0$ & $3,184,700.0$ \\
\hline$\%$ & 65.7 & 44.3 & 8.1 & 0.5 & 10.8 & 23.6 & 100.0 \\
\hline 2003/04 Value & $2,357,600.0$ & $1,539,900.0$ & $312,100.0$ & $16,100.0$ & $400,300.0$ & $850,400.0$ & $3,608,300.0$ \\
\hline$\%$ & 65.3 & 42.7 & 8.7 & 0.5 & 11.1 & 23.6 & 100.0 \\
\hline
\end{tabular}

Source: Ministry Of National Planning And Economic Development, Central Statistical Organization

Table 2. Changes of Agricultural and Pulses Exports

\begin{tabular}{ccccccccccc}
\hline & $1985 / 86$ & $1989 / 90$ & $1990 / 91$ & $1992 / 93$ & $1994 / 95$ & $1996 / 97$ & $1998 / 99$ & $2000 / 01$ & $2001 / 02$ & $2003 / 04$ \\
\hline $\begin{array}{c}\text { Agricultural Export Value } \\
\quad \text { Million Kyats) }\end{array}$ & 1,126 & 432 & 942 & 1,299 & 2,478 & 1,981 & 1,890 & 2,312 & 3,021 & 2,808 \\
Share in Total Export Value & $43.9 \%$ & $15.2 \%$ & $31.9 \%$ & $36.2 \%$ & $45.8 \%$ & $36.1 \%$ & $28.0 \%$ & $18.9 \%$ & $17.6 \%$ & $14.0 \%$ \\
$\quad \begin{array}{c}\text { Pulses Export } \\
\quad \text { Volume (10,000 tons) }\end{array}$ & 8.9 & 0.6 & 19.5 & 44.9 & 42.5 & 59.5 & 62.2 & 83.1 & 10.35 & 10.38 \\
$\quad$ Value (Million Kyats) & 238 & 123 & 515 & 667 & 799 & 1,272 & 1,135 & 1,658 & 1,898 & 1,760 \\
$\quad$ Share in Total Agricultural & $21.1 \%$ & $28.5 \%$ & $54.7 \%$ & $51.3 \%$ & $32.2 \%$ & $64.2 \%$ & $60.1 \%$ & $71.7 \%$ & $62.8 \%$ & $62.7 \%$ \\
$\quad$ Export & & & & & & & & & &
\end{tabular}

Source: Statistical Year Book, Central Statistical Organization, Ministry of National Planning and Economic Development 
(SAMB), the intention of which was to monopolize the trade in rice, the greatest item for the country. However, the SAMB only monopolized the trade in rice for export, while the trade in rice for domestic marketing was in the hands of private dealers.

Only one year after coming to power in 1962, the revolutionary government started a nationalization policy in various areas of the country, and the nationalization of the marketing sector was the first and most thoroughgoing. As a result of the nationalization of the marketing sector, private trade in rice and other major farm products for domestic markets also came to be prohibited, and the collection of those products also became the domain of government. The SAMB was reorganized into the Union of Burma Agricultural Products Marketing Board (UBAM) which set up paddy buying depots all over the country to collect paddy. It became compulsory for farmers who produced paddy and other major crops to deliver a quota of each of those crops harvested to the government at officially fixed prices. This procurement system was continued by the socialist government since the country had been powered by "Burmese Way to Socialism" in 1974 (Saito, 1980).

Agriculture under Burmese way to socialism was controlled by the government in terms of production, marketing, processing and transportation. This was caused by the adoption of the following policies: (1) the state-ownership of the land, (2) procurement of agricultural products by the government at the low prices, and (3) the government control over cropping pattern and decision. The procurement system was intended to eliminate the influence of non-Burmese merchants on the trade of agricultural produce, accumulate foreign currency by monopolizing the export of agricultural products by the government and supply the food to the urban consumers at low prices. Government controlled cropping pattern to support procurement system by prohibiting farmers to change their crops which are not procured by the government.

The compulsory delivery quota absorbed almost all marketable surpluses of agricultural products (Saito, 1980, Mya Than and Nishizawa, 1990). The existence of these system discouraged farmers to increase agricultural production, particularly through increasing yield per acre. The compulsory delivery system at low official prices decreased the level of profitability of agricultural production and consequently, negatively impacted on agricultural productivity and national economic development. These government interventions reduced the farm incomes by lowering the farm gate price and were significantly disincentives to farmers in making output and marketing decisions. In the 18 countries, studied, government policies that taxed agriculture (such as compulsory delivery policies) reduced prices received by farmers, on average, by 30\%. Therefore, crop procurement system taxed the farmers reduce farm incomes and lowered the farm output from a recent study of the cross-country evidence (Krueger et al., 1991).

\section{Marketing policies after agricultural market reforms}

The system of socialist agricultural policies that had existed since 1962 had been dismantled after 1988. The forced procurement of output of major agricultural crops including paddy, pulses, maize and oilseeds by the government was discontinued and private trading of these was permitted. Then, government control over cropping planning and decisions was relaxed substantially and farmers were free to make their own cropping decisions except on paddy land and some industrial crops, like sugarcane, cotton, etc., which are important for State One Enterprises. Except for rice and some industrial crops, private exports of agricultural products had also been permitted since 1988. Private sector provision of agricultural inputs such as fertilizers and pesticides was also allowed for trading. After government policy allowed the private sector to procure and export pulses freely at market prices, it has resulted in the rapid increase in the acreage, production, the volume and value of pulses export. This again reveals the superiority of market economy over strict government controls in the effort to boost production and export. The marketing and pricing policies of pulses have been fully liberalized by privatization and, consequently, attained huge increases in the production and export in spite of meager technology improvements.

\section{IMPACT OF MARKET REFORM ON PULSES' SECTOR}

Before and after agricultural market reform, the trend of sown acreage and production of black gram, green gram, pigeon pea and soybean is completely different, while those of chickpea is not significantly different because of slightly government intervention and poor crop competition with other exportable crops like Pigeon pea and green gram (Fig. 2).

The sown acreage and production of black gram, green gram and pigeon pea has been dramatically increasing after market reform and export liberalization. In soybean, the sown area and production was sluggish until 1995/96 because of lack of export demand. Since after 1995-96, the trend of sown area and production has been increasing significantly because of higher demand for soybean cakes from fishery sector for domestic aquatic feed, but there is still lack of export demand though.

The impact of market reform can be scrutinized by growth rates of sown area, production (Mt) and yield of pulses (Table 3).

Before market reform, the growth of sown areas and production was stagnated in all pulses. In the case of growth rate of sown area, it was less than $1 \%$ in green gram and negative rate of $1 \%$ in pigeon pea. After market reform, cultivation area increased noticeably with an annual growth rate of 12\%, 16\%, 13\% and 11\% for black gram, green gram, pigeon pea, and soybean respectively. However, the growth rate for chickpea was only $1 \%$ for slight government intervention and lesser 

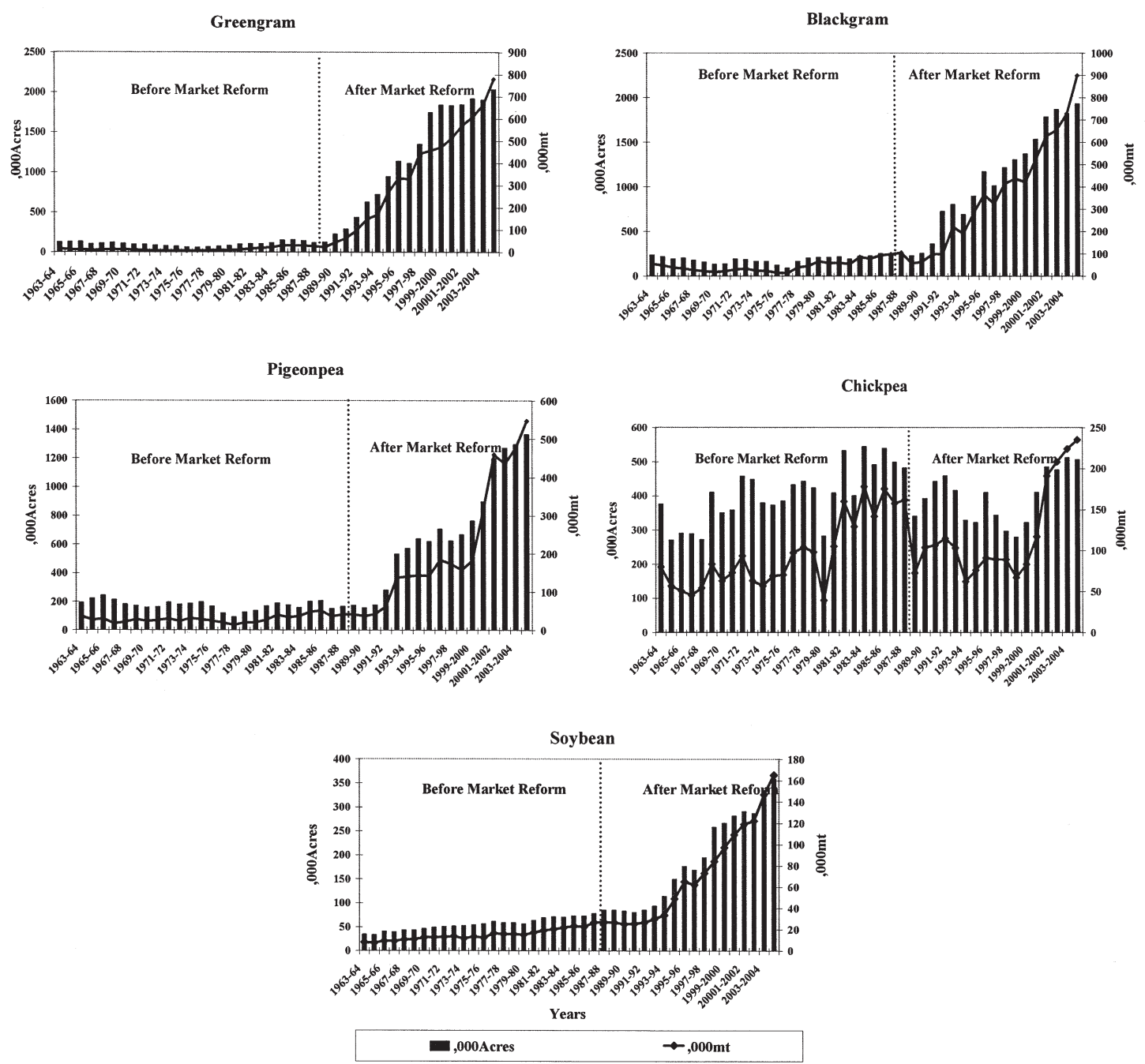

Fig. 2. Trends of Sown Acreage and Production (1963-64 to 2004-05).

Table 3. Growth Rates of Sown Area, Production and Yield of Pulses

\begin{tabular}{clcc}
\hline \multirow{2}{*}{ Crops } & Subjects & Before Market Reform & After Market Reform \\
\cline { 3 - 4 } Black gram & Sown area & $(1963-1987)$ & $(1988-2004)$ \\
& Production & 1 & 12 \\
& Yield & 5 & 16 \\
\multirow{5}{*}{ Green gram } & Sown area & 4 & 2 \\
& Production & 0.4 & 16 \\
& Yield & 4 & 20 \\
Pigeon pea & Sown area & 4 & 3 \\
& Production & -1 & 13 \\
& Yield & 2 & 3 \\
& Sown area & 3 & 1 \\
& Production & 2 & 6 \\
& Yield & 5 & 3 \\
& Sown area & 3 & 11 \\
& Production & 3 & 13 \\
& Yield & 5 & 2 \\
\hline
\end{tabular}


competitiveness to major exportable pulses of pigeon pea and green gram. The growth rate of production also increased significantly to $16 \%, 20 \%, 17 \%, 13 \%$ for black gram, green gram, pigeon pea and soybean respectively. It is noteworthy that due to market reform there was rapid and huge increase in acreage and production of pulses, especially in exportable crops, black gram, green gram and pigeon pea, in response to export market demand. But, there was no significant change of growth rate for yield in both before and after market reform. This is evident that government did not endeavor enough in research and development for crop improvement, technology and extension services.

The impact of agricultural market reform is also significant on trends of nominal and real price of pulses (Fig. 3 and Fig. 4).

After market reform, nominal price of all pulses increased dramatically year after year for export demand. The signals of price reflected instantaneous adjustment of international price on domestic price because of export liberalization. Just after market reform, while low inflation, real prices increased. However, it fell down because of high inflation around 1994. After 1994, real prices slightly and gradually increased until 2000. After that, high inflation came again and real prices sharply fell down again consequently. Thus, price of pulses was strongly affected by macroeconomic policy like high inflation and government should carry out appropriate implementation of macroeconomic policy in order to reduce the inflation

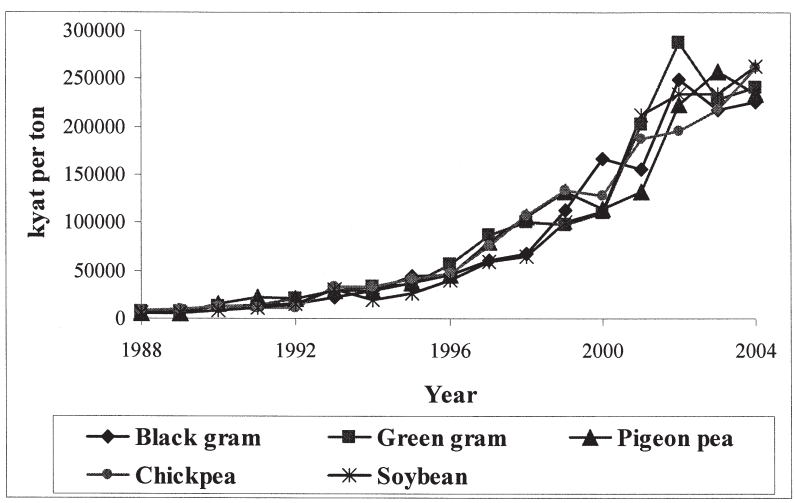

Fig. 3. Trend of Nominal Price of Pulses at Harvest Time.

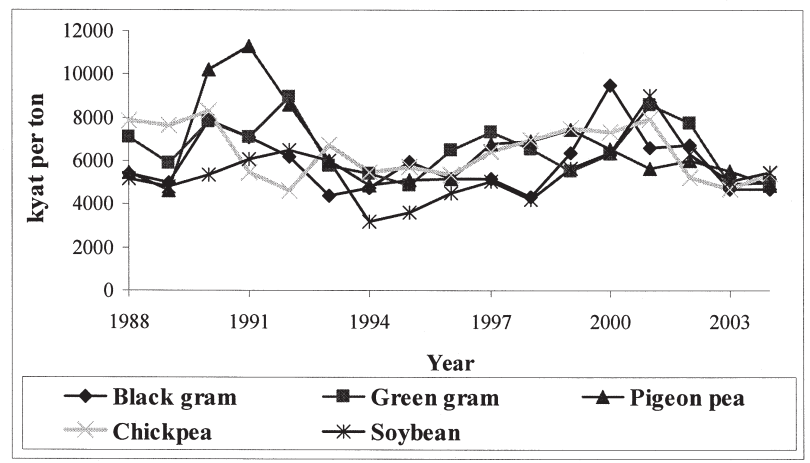

Fig. 4. Trend of Real Price of Pulses at Harvest Time (Deflated by General Consumer Price Index, $1986=100$ ). and stabilize agricultural prices.

The analysis of pulses sector could reveal the comprehensive view on the effects of agricultural pricing and marketing policies, as it is not only the second largest sown areas of total pulses sown area, but also contributing huge share of export value among other agricultural commodities, and simultaneously and significantly responding to agricultural market reform.

\section{METHODOLOGY}

\section{Issues in the theoretical considerations of agricul- tural supply models}

Agricultural supply response represents the response of agricultural outputs to changes in agricultural prices or to agricultural incentives. Moreover, agricultural supply or output can be captured in any of the following: (a) sown acreage, (b) yield per acre, and (c) production amount.

Certainly, issues of market level agricultural supply are central to development strategies, and there will be a prerequisite that the agricultural sector should provide a growing surplus of agricultural produce for increasing farm incomes and overall economic development of the nation. The contribution which agricultural sector can make in above areas will depend on the responsiveness of farmers to economic incentives and to price signals in particular. Theoretically, supply function of agricultural crops will depend on the price of commodity, the price of other competing commodities, the price of joint commodities, the price of inputs, the state of technology, the nature of the environment and the state of institutions. The supply function can be expressed as follow:

\section{Supply $=\mathrm{f}$ (expected output price, expected price of alternative crops, input price, technology, environment, institutions)

But there are limitations to use all possible variables affecting supply function in analysis because of limited number of observations and the statistical problems of serial correlation in disturbance term. Moreover, in developing countries like Myanmar, price is the prominent factor to determine sown acreage of crops. Therefore, the hypothesized supply function in this article is expressed as follows:

$$
\text { Supply }=\mathrm{f}(\text { expected output price })
$$

In equation (2), it is a static model that a change in an explanatory variable will induce an instantaneous and complete response in supply and that there are no delays in adjustment. In fact, there are a number of reasons for delayed adjustment in agricultural markets. Therefore, it must be differentiated between the immediate/short-run response and long-run response. Thus, a dynamic approach, which recognizes the time lags in agricultural supply response, should be adopted in empirical analysis. 


\section{The Nerlove partial adjustment model}

The empirical studies have largely concentrated on estimating the price elasticity of agricultural supply. In most cases, the so-called Nerlove-model (Nerlove 1979) has been employed. This method involves the estimation of a partial adjustment model of agricultural production for one particular country. The supply function of the partial adjustment model has the general form;

$$
\ln A_{t}^{*}=\beta_{1}+\beta_{2} \ln P_{t-1}
$$

Where; $A_{t}^{*}$ denotes desired acreage at time t, and $P_{t-1}$ denotes the output price at time $\mathrm{t}-1$.

Furthermore, it is assumed that the dynamics of supply are captured by;

$$
\ln A_{t}-\ln A_{t-1}=\lambda\left(\ln A_{t}^{*}-\ln A_{t-1}\right)
$$

Where; $A_{t}$ is actual acreage, and

$\lambda$ is partial adjustment coefficient.

According to equation (4), adjustment costs imply that the actual change in acreage between two periods is only a fraction of the change required to achieve the optimal acreage level $A_{t}{ }^{*}$. Substituting, (4) into (3) and rearranging gives;

$$
\ln A_{t}=\beta_{1} \lambda+\beta_{2} \lambda \ln P_{t-1}+(1-\lambda) A_{t-1}+\mu_{t}
$$

From this model, the following can be investigated:

(a) the short-run reaction of $A_{t}$ to a unit change in $P_{t-1}$ is $\beta_{2} \lambda$;

(b) the long-run reaction is given by $\beta_{2}$; and

(c) an estimate of $\beta_{2}$ can be obtained by dividing the estimate of $\beta{ }_{2} \Lambda$ by one minus the estimate of $(1-\lambda)$, i.e. $\beta_{2}=\beta_{2} \lambda /[1-(1-\lambda)]$.

Symbols and definitions of the variables used:

$A_{t}=$ Area planted at time $\mathrm{t}$

$P_{t-1}=$ Prices deflated by general consumer price index at time $\mathrm{t}-1$

$A_{t-1}=$ Area planted at time $\mathrm{t}-1$
The data sets used were annual observations covering the period 1988-2004 from "Myanma Agricultural Statistics, 1997 and 2004". General consumer price index was used from "Various Issues of Monthly Selected Economics Indicators", by Central Statistical Organization, Ministry of National Planning and Economic Development.

\section{RESULTS AND DISCUSSIONS}

The results of acreage response function for pulses by ordinary least square method is shown in Table 4 .

Serial correlation was tested by Durbin-Watson statistics. Durbin-Watson statistics ranged from 1.43 to 2.38 and were acceptable for the problems of serial correlations. The values of the coefficient of determination, $R^{2}$, having $92 \%, 98 \%, 95 \%, 62 \%$, and $96 \%$ for black gram, green gram, pigeon pea, chickpea and soybean respectively indicated that the model is goodness of fit for data generating process.

The coefficients of lagged acreage were highly significant in all pulses acreage estimates. According to the theory, these coefficients being positive and less than one implied that long-run elasticities exceed short-run elasticities, i.e., a period of more than a year was required for pulses' farmers to be able to fully adjust their planting decisions in response to exogenous shocks. Except for soybean, the acreage of other pulses significantly responded to prices at $1 \%$ significant level for green gram and pigeon pea; and at 5\% significant level for black gram and chickpea. The exported amount of soybean was much less than that of other four pulses. Thus, soybean price could not be able to adjust with international market price and consequently, has no incentives for farmers. The extension of acreage of soybean will be limited because large amount of marketable surplus over domestic demand will cause a sudden decrease of price resulting hesitation to farmers for area expansion. Acreage of other exportable pulses can be expanded as much as possible for availability of land

\begin{tabular}{|c|c|c|c|c|}
\hline Crops & Lagged Price & Lagged asreage & $\mathrm{R}^{2}$ & $\begin{array}{c}\text { Durbin }[\text { Watson } \\
\text { Statistics }\end{array}$ \\
\hline Black gram & $\begin{array}{c}0.26 \\
(2.57)^{* *}\end{array}$ & $\begin{array}{c}0.85 \\
(13.52)^{* * * *}\end{array}$ & 0.92 & 2.29 \\
\hline Green gram & $\begin{array}{c}0.27 \\
(6.63)^{* * * *}\end{array}$ & $\begin{array}{c}0.84 \\
(32.43)^{* * * *}\end{array}$ & 0.98 & 2.38 \\
\hline Pigeon pea & $\begin{array}{c}0.22 \\
(3.06)^{* * * *}\end{array}$ & $\begin{array}{c}0.87 \\
(18.49)^{* * * *}\end{array}$ & 0.95 & 1.43 \\
\hline Chickpea & $\begin{array}{c}0.31 \\
(2.49)^{* *}\end{array}$ & $\begin{array}{c}0.79 \\
(9.28)^{* *}\end{array}$ & 0.62 & 1.75 \\
\hline Soybean & $\begin{array}{c}0.02 \\
(0.38)^{\mathrm{ns}}\end{array}$ & $\begin{array}{c}0.99 \\
(21.58)^{* * *}\end{array}$ & 0.96 & 1.43 \\
\hline
\end{tabular}
and capital because all production of marketable surplus

Table 4. Acreage Response Functions for Pulses by OLS

Note: All figures in parenthesis (...) are t】values;

$* * *=$ significant at $1 \%, * *=$ significant at $5 \%, *=$ significant at $10 \%$, ns $=$ not significant 
goes to export market, especially India.

In the case of chickpea, even though there was slight intervention in domestic and export market, it was exportable every year due to large market demand from India. Therefore, chickpea underwent a process of rapid adjustment with the international market price and consequently, the price provided the incentives for farmers. Actually, India was the largest export market for Myanma pulses, especially for black gram, green gram, pigeon pea and chickpea. However, there was almost no demand for soybean from India. For other export markets of soybean, it is still challenging for qualities and food safety issues.

Estimated coefficients of partial adjustment and short-run and long-run elasticities are shown in Table 5.

Table 5. Estimated Coefficients of Adjustment $(\lambda)$ and Price Elasticities of Pulses Acreage

\begin{tabular}{llcc}
\hline \multirow{2}{*}{ Crops } & $\lambda$ & \multicolumn{2}{c}{ Elasticity } \\
\cline { 3 - 4 } & & Short-run & long-run \\
\hline Black gram & 0.15 & 0.26 & 1.68 \\
Green gram & 0.16 & 0.27 & 1.68 \\
Pigeon pea & 0.13 & 0.22 & 1.62 \\
Chickpea & 0.21 & 0.31 & 1.48 \\
\hline
\end{tabular}

The partial adjustment coefficients were 0.15, 0.16, 0.13 , and 0.21 for black gram, green gram, Pigeon pea and chickpea respectively. The coefficients indicated that economic adjustment was quite slow in response to area of pulses. The short-run elasticities were low, because main inputs, such as land, labor and capital were fixed. In other words, $10 \%$ increase in the of price pulses would bring the increase in area planted only $2.5 \%, 2.7 \%, 2.2 \%$, and $3.1 \%$ for black gram, green gram, pigeon pea and chickpea respectively. Although short-run elasticities were less than (1), which were considered inelastic theoretically, long-run elasticities were larger than (1), being considered elastic in acreage response. In long-run, 10\% increase in pulses price would bring the increase in area planted 16.8\%, 16.8\%, $16.2 \%$, and $14.8 \%$ for black gram, green gram, pigeon pea and chickpea respectively. So, it could be said that prices were incentives for farmers to plant more areas especially in exportable crops, black gram, green gram, pigeon pea and chickpea; and agricultural price and market reform with domestic and export liberalization were important factors for positive response to acreage decision of farmers.

\section{CONCLUSIONS}

Compulsory procurement of agricultural products at very low prices, undertaken in order to keep consumer price down, is likely to have adverse effects on production growth and will not be effective way of mobilizing resources from agricultural sector for industrialization in the long run. Getting price incentives through to farmers should be considered as an effective mean for price policy of producers with highest priority. There is no doubt that farmers respond price incentives, especially in export crops.

Even though the crop like soybean is liberalized in domestic and export markets, there is prerequisite for government to endeavor quality improvement with efficient safety issues for international markets, and to explore the opportunity of export markets with reliable trade laws and regulations. The existence of adequate agricultural infrastructure and availability of improved technologies are favorable to farmers' responses to incentive prices. Yield per area is also important factor to increase the growth of agricultural production. It is still sluggish before and after market reform. Investment in technology development for increasing yield per area will be an indispensable ingredient of agricultural policy and development, and an urgent requirement for a quick rise in productivity in agriculture.

As a whole, agricultural market reform, with price incentive to farmers, can induce the motivation of production. However, complementary interventions for the improvement of infrastructure, marketing, access to inputs and credits, production technology etc are still prerequisite. It can be concluded that agricultural market reform with domestic and export liberalization in pulses' sector is an evidence of successful and fruitful implementation of policy reform on agriculture, with a strong incentive for encouraging area expansion by farmers' response to price as well as for increasing export promotion, fuelling to economic growth of the nation.

\section{REFERENCES}

Andrew, Oliver Morrissey and Charlotte Vaillant 1998 Aggregate Export and Food Crop Supply Response in Tanzania. Credit Research Paper, 4: 129-147

Chibber, A. 1989 The aggregrate Supply Response in Agriculture: A Survey. In "Structural Adjustment and Agriculture: Theory and Practice in Africa and Latin America", ed. By S. Commander, Overseas Development Institute, London, pp. 45-68

Dimitrios Asteriou and Stephen G. Hall 2007 Applied Econometrics: A Modern Approach Using Eviews and Microfit(Revised Edition). Palgrave Macmillan, New York

FAO 1987 Agricultural Price Policies: Issues and Proposals. Rome, Italy

Hla Kyi 1997 Production, consumption and marketing of selected pulses in Myanmar. Yangon, Myanmar

Hla Kyi, Mruthyunjaya, Naseer, A. K., Rupasena, L. and J. W. T. Bottema 1997 Market Prospects for Pulses in South Asia: International and Domestic Trade. CGPRT centre, Indonesia

Krueger, A. O., M. Schiff, and A. Valdes 1988 Agricultural incentives in developing countries: Measuring the Effect of Sectoral and Economy wide Policies. World Bank Economic Review, 2(3): 255-272

Krueger, A. O. 1992 The Political Economy of Agricultural Pricing Policy: A Synthesis of the Political Economy of Developing Countries. The John Hopkins University Press, Baltimore, U.S.A

Mattias Lundberg 2005 Agricultural Market Reforms. In "Analyzing the Distributional Impact of Reforms: A practitioner's guide to trade, monetary and exchange rate policy, utility provision, agricultural markets, land policy, and education", ed. by Aline Coudouel and Stefano Paternostro, The 
World Bank, Washington, DC, pp. 145-212

Maurice Schiff and Claudio, E. M. 1995 Aggregate Agricultural Supply Response in Developing Countries, Policy Research Working Paper 1485, International Economics Department, International Trade Division, The World Bank, Washigton. D.C.

Mundlak, Y., D. Cavallo, and R. Domenech 1989 Agriculture and Economic Growth in Argentina, 1913-84. IFPRI Research Report, 76, Washington, D.C.

Nerlove, M. 1956 Estimation of the Elasticities of Supply of Selected Agricultural Commodities. Journal of Farm Economics, 38: 496-509

Nerlove, M. 1958 Distributed Lags and Estimation of Long-Run Supply and Demand Elasticities: Theoretical Considerations. Journal of Farm Economics, 40: 301-311

Nerlove, M. 1958 The Dynamics of Supply: Estimation of Farmers' Response to Price. Johns Hopkins University Press, Baltimore, U.S.A.

Nlandu Mamingi 1996 How Prices and Macroeconomic Policies Affect Agricultural Supply and the Environment. Policy Research Working Paper, 1645, Policy Research Department. The World Bank.,Washington, DC.

Noboru Watanabe, Mikio Murasaki and Shin Minematsu 1997 The Myanmar Economy: Its Current Status and Future Challenges. OECF Journal of Development Assistance, 2(2): 117-151

Nursen Albayrak 1998 Wheat Supply Response: Some Evidence on Aggregation Issues, Development Policy Review, 16: 241-263

Okamoto, I. 2004 Agricultural Marketing Reform and Rural Econmy in Myanmar: The Successful Side of the Reform. Institute of Developing Economies, JETRO, Tokyo

Parikh, A. 1971 Farm Supply Response: A Distributed Lag Analysis. Oxford Bulletin of Economics \& Statistics, 33(1): $57-72$

Rainer Thiele 2000 Estimating the Aggregate Agricultural Supply Response: A Survey of Techniques and Results for Developing Countries. Kiel Working Paper, 1016, Kiel Institute of World Economics, Kiel, Germany

Saito, T. 1980 Farm Household Economy under Paddy Delivery System in Contemporary Burma. Developing Economies, 19(4), Institute of Developing Economies, JETRO, Tokyo

Thanda Kyi 2000 Market Induced Shifts in Agricultural Supply and Effects on Trade Patterns in Myanmar. $\mathrm{PhD}$ Dissertation, University of Hohenheim, Stuttgart, Germany

Tin Soe 2005 Myanmar in Economic Transition: Constraints and Related Issues Affecting the Agriculture Sector. Asian Journal of Agricultural and Development, 1(2): 57-68

Tin Soe and Brian S. F. 1990 An Economic Analysis of Burmese Rice-Price Policies. In "Myanma Dilemmas and Options: The challenges of Economic Transition in the 1990s", ed. by Mya Than and Joseph L.H. Tan, Institute of Southeast Asian Studies, Singapore, pp. 117-166 